TAE-HYOUNG TOMMY GIM, Ph.D.

E-mail: taehyoung.gim@snu.ac.kr

Graduate School of Environmental Studies

Interdisciplinary Program in Landscape Architecture

and Environmental Planning Institute

Seoul National University

Gwanak-ro 1, Gwanak-gu, Building 82, Room 222

Seoul 08826, South Korea
Transport and Sustainable Development Original Scientific Paper Submitted: 13 Nov. 2019 Accepted: 19 Feb. 2020

\title{
ANALYSING THE EFFECTS OF LAND USE ON THE CHOICE OF INTRA-ZONAL TRIP DESTINATIONS - A COMPARISON BETWEEN WEEKDAY AND WEEKEND TRAVEL
}

\begin{abstract}
Among the studies on the land use - travel relationship, few investigated it regarding weekend travel and destination choice. This study accordingly evaluates how the land use - destination choice relationship differs between weekdays and weekends using two multinomial logistic regression models in which the destination is classified into three types: microzone inside, microzone outside - macrozone inside, and macrozone outside. Major findings are that the choice of automobile alternatives for travel and their ownership are associated with the choice of the microzone inside while employment and income contribute to external trips. Among land use variables, nighttime population density turns out to be the only land use variable that consistently increases internal trips in all cases, regardless of the zone size and weekday - weekend difference, whereas daytime population density does not become significant in any case. Also, land use entropy and street connectivity are found to discourage a trip that moves from the microzone to the macrozone and transit system variables to facilitate a trip that goes beyond the microzone. Particularly, between two types of transit system variables, the choice of the microzone is likely to be associated with low bus stop density on weekdays and low metro station density on weekends.
\end{abstract}

\section{KEY WORDS}

land use; destination choice; weekday - weekend comparison; multinomial logistic regression; Seoul;

\section{INTRODUCTION}

Transportation researchers have been investigating the relationship between land use and travel behaviour for well over half a century [e.g. 1, 2] through which they reached an agreement on the overall significance of the relationship [3]. A remaining issue is that actually, the details are not in agreement $[4,5]$. In particular, between two concepts that constitute the relationship, first, regarding land use (or for transportation planners who consider an effective land use intervention), a long-standing question is which variable is crucial among different land use variables [6,7]. A second, more critical issue is related to travel behaviour: most previous studies were concerned with weekday travel [8-11], so in terms of external validity, the general significance of the land use - travel relationship can be concluded only on weekday travel, that is, in fact, little is known about weekend travel. Studies based on weekday travel may be limited in offering implications in understanding the relationship that land use has with weekend travel $[6,12-15]$ and thus, studies have been requested to use weekend data to examine the land use - weekend travel relationship [16]. As a rationale for this request, relative to weekday travel whose purposes are mostly compulsory (also called mandatory), weekend travel has a high proportion of discretionary (or non-mandatory) purposes [17], so the choices of the trip departure/arrival time and destination are less usual and structured $[18,19]$, that is, highly flexible $[20,21]$. (The inflexibility of weekday travel causes it to face somewhat inevitable congestion, in particular time periods and places.) According to such a flexibility, land use variables are expected to affect weekend travel in different magnitudes. As such, studies began in the late 2000s [e.g. 22], but how land use affects weekend travel is still relatively unknown. It is because in relation to the temporal and spatial 
variability of weekend travel, empirical data and research on weekend travel have not been accumulated [23].

The purpose of this study is to reveal the relationship that land use has with travel on weekends. As has been relatively less investigated among various travel measures [24], it particularly deals with the choice of the trip destination, that is, how the land use - destination choice relationship differs between weekdays and weekends. As three major travel measures, previous studies mostly analysed how compact land use differentiated total travel distance, travel mode choice, and trip frequency and according to a meta-analysis [24], the land use effect tends to be attenuated in the above order.

First, the tendency that the land use effect is relatively weaker on mode choice than on total travel distance may imply that a particular mode of transportation is usually used $[25,26]$. Second, why trip frequency does not have a large variation compared to total travel distance $[27,28]$ may be that the effect of compact land use is in the form of a shortened trip length [29]; in the equation of "total travel distance $=$ trip frequency $\times$ unit trip length", if the variation in the total distance does not originate from the trip frequency variation, it can then be attributed to the variation in the other term, trip length. This trip length reduction is necessarily accompanied by changes in the physical origin - destination distance [29], that is, those in trip destinations closer to the origins [30]. In the same sense, Ewing and Cervero [24] suspected through a meta-analysis that the utility of compact developments is not the overall travel reduction (automobile travel in particular), but trip-chaining or destination internalization. However, despite this suspicion, few attempted tour-based and destination-choice studies, each of which can test whether trip-chaining is facilitated instead of isolated trips and whether external trips are replaced by internal trips. The lack of tour-based and destination-choice studies made it impossible to conduct a meta-analysis of trip-chaining and destination internalization and of the two measures, the studies on destination internalization were even fewer [24, 31, 32 ], and the accumulation of such studies was urgently requested [24, 33]. In response to the request, this study evaluates the destination choice among other travel measures.

Another difference from the previous studies is that based on the location of the destination, this study categorizes the trip into three types rather than just two (i.e. within- and between-zone trips). They are micro TAZ (traffic analysis zone) inside trips, micro TAZ outside - macro TAZ inside trips, and macro TAZ outside trips (to be discussed later).

In short, a major strength of this study is that it employs the same sample to examine the impact of land use on destination choice during weekdays and weekends. In particular, trip destinations are classified into multiple categories and the choice is analysed through respective weekday and weekend multinomial logistic regression models.

\section{LITERATURE REVIEW}

As stated above, among studies on the land use - travel relationship, few used multi-day travel data on weekends as well as on weekdays and referred to the destination choice for the travel measurement. Combined together, studies that analysed multiday data for an analysis of destination choice are even fewer. First, regarding the multi-day studies, as initiated in the early 2000s [34], most of them are based on data from the GPS/accelerometer and/or first-hand primary survey and thus, they necessarily sampled individuals at a small size in a couple of representative areas on a micro scale.

Troped et al. [35] used only GPS/accelerometer devices to collect consecutive two-weekday and two-weekend-day data for an analysis of the land use - walking/physical activity relationship. Forsyth et al. [14] also examined how land use is associated with walking/physical activities, but differences from Troped et al. [35] are that firstly, travel behaviour was measured for an entire week, rather than for four days, and secondly, travel data were collected not only with the accelerometer, but also through a survey (travel diary). Ogilvie et al. [36], by contrast, used only survey data to analyse the land use effect on active travel and physical activity variations. A difference of this study from the above two is that its analytical model included a dummy variable of whether a trip was generated on weekdays or weekends. As such, the study was capable of analysing the statistical significance of the weekday - weekend travel difference. As a step forward from those studies that used a weekday - weekend difference dummy, Lin and $\mathrm{Yu}$ [37] and Written et al. [38] specified respective weekday and weekend models in which weekday and weekend travel was separately analysed. A difference between the two studies is that to evaluate leisure/non-motorized travel, $\mathrm{Lin}$ and $\mathrm{Yu}$ [37] conducted a sample survey in three 
schools and for an analysis of leisure-time physical activities, Written et al. [38] used seven-day accelerometer data in addition to survey data.

Compared to small-scale first-hand (primary) surveys, large-scale public (secondary) surveys are difficult to manage, so they are typically conducted only for one or two days without taking into account weekend travel. However, including the 2006 KHTS (Korean Household Travel Survey), which is adopted in this particular study, some public travel surveys were carried out also on weekends. Thus, they could be used to check the weekday - weekend travel difference or to specify separate weekday and weekend travel models. Cervero and Duncan [39] used the data of the 2000 BATS (San Francisco Bay Area Travel Study), which was conducted for one weekday and one weekend day, to explore the land use effect on the choices of the walk and bike in respective binary logistic regression models. In the models, a dummy was included to test the significance of the weekday - weekend travel difference. Lee et al. [22] used the household travel survey of Strategies for the Metropolitan Atlanta's Regional Transportation and Air Quality (SMARTRAQ) and unlike Cervero and Duncan [39], they specified separate weekday and weekend travel models to analyse the relationship between land use and total travel time. As with Lee et al. [22], if separate models are evaluated, one can compare their coefficients to examine which variables cause the weekday - weekend difference rather than merely testing whether the difference exists. Meanwhile, Lee et al. [22] evaluated the weekday and weekend models using different samples. In this case, the interpretation of the model results is not straightforward insomuch as differences in the results may originate, at least partially, from those in the characteristics of the samples that were not controlled, not from the weekday - weekend difference. Therefore, this study applies the same sample to the two, weekday and weekend models in an attempt to control the sample differences.

Regarding destination choice, studies began in the mid-2000s to systematically investigate this topic, which is theoretically related to the strategy of the jobs - housing balance [40]. Since the strategy was proposed by Cervero [41], its effectiveness has been empirically supported [42-44] or rejected [30, 34, 45]. A limitation of these studies is that they mostly analysed travel behaviour by evaluating commuting time/distance rather than destination choice [40].
Meanwhile, studies on destination choice typically refer to the TAZ and separate the destination into its internal and external locations (see the following studies); this study also accepts the TAZ reference. Traditionally, TAZ was used as a unit of analysis for aggregate data studies [e.g. 31, 32, 46, 47]. These studies may provide practical insights for travel demand forecasting [46, 47], but they have been consistently found to be less useful for explaining travel behaviour than individual-level analyses such as this particular study $[46,48]$.

First, through expert interviews in Austin, Texas, Zhang et al. [49] identified its 42 TAZs with mixed land uses and compared how their travel patterns, as measured in one day between Monday and Thursday, are differentiated from the other 450 general TAZs in the city using the descriptive statistics of the internal trip rate. By contrast to such a descriptive analysis, Soltani and Ivaki [50] and Manaugh and El-Geneidy [51] employed an inferential method, OLS regression, in order to test how land use variables affect (one-weekday) TAZ inter-zonal travel in Shiras, Iran and intra-zonal travel in Montreal, Canada, respectively, while controlling socio-demographic variables. This study differs from the two inferential studies since it simultaneously considers intra- and inter-zonal travel. Also, considering the limitation that is acknowledged by Soltani and Ivaki [50], this study tests how a land use variable exerts an effect in the other range of the destination (i.e. the previous studies investigated either the inside or the outside of the zone, not both). For example, Soltani and Ivaki [50] analysed only the zone outside and found that land use mix does not significantly affect inter-zonal travel, but they nevertheless suspected that it might affect the generation of intra-zonal travel. A second issue is that as admitted by Manaugh and El-Geneidy [51], the two studies did not use travel data collected for multiple days including weekends and thus, their results have limited implications especially on weekend travel.

As a study that considered both intra- and inter-zonal travel - this is an approach recommended by Soltani and Ivaki [50] - Sadek et al. [52] used two circular buffers from the central TAZ of Erie County, the State of New York. The buffers contained 33 percent and 66 percent of the total 402 TAZs in the county. Then, the researchers evaluated the choices of the four destination areas (inside of the origin TAZ vs. others, outside of the origin - 33 percent TAZs vs. others, 33 percent - 66 percent 
TAZs vs. others, and outside of the 66 percent TAZs vs. others) in four binary logistic regression models. The strength of the study is that the destinations were classified into multiple categories, not just two (i.e. inside or outside the zone). As a step forward from Sadek et al. [52], this study specifies the destination choice as a multinomial, not binomial option, whereby the competitive relationships among multiple destination categories can be analysed. That is, for example, a competition analysed in this study is not between the origin TAZ and all the others, but more specifically, between the TAZ and those in the 33 percent - 66 percent range. Moreover, the statistical tests are conducted on whether the way of categorizing destinations is valid: Wald $\chi^{2}$ tests and LR (Likelihood Ratio) $\chi^{2}$ tests for the alternative combination (to be discussed later). Lastly, Sadek et al. [52] ultimately intended to estimate the population parameters for this purpose, they imposed weights on observations - but, inasmuch as trips were measured only for one day (between Monday and Friday), their findings provide limited implications on weekend travel [51]. On the contrary, this study specifies a separate model for weekend travel along with a weekday travel model.

Indeed, empirical studies on how the land use - travel relationship is differentiated by the scale of the trip measurement are few, relative to those studies on the scale of the land use measurement (to be discussed below). For instance, as suspected by a study by Zhang et al. [53] and its follow-up by Hong et al. [54], in order to evaluate how micro-scale land use has an effect on automobile commuting trips, rather than on walking shopping trips, a larger area may be appropriate for the trip measurement. As an exception that considered the trip measurement scale, Sadek et al. [52] conducted an exploratory study on the range of the local land use effect. They classified the county TAZs into distance-based four categories and through four binary logistic regression models, subsequently analysed how land use entropy in the origin-TAZ affects the choice and no choice of each of the four categories. What differentiates this study from Sadek et al. [52] is that various land use variables were considered, including the entropy, and competitions among multiple destination zones were analysed in the same multinomial logistic regression models.

\section{METHODOLOGY}

For the purpose of analysing the relationship between land use and destination choice separately for weekday and weekend travel, this study specified the logistic regression models. In addition to land use variables, the models included as covariates trip characteristics and individual and household socio-demographics. Due to data limitations, attitudes, which are another major determinant of travel, were not controlled. However, insomuch as attitudes are formed on the basis of socio-demographic characteristics [55], one can say that they were somewhat considered for the purpose of statistical control. This study chooses the micro TAZ as the unit of observation for land use (notably, unit of analysis = trip). In Seoul, the micro TAZ is the smallest scale on which land use information is collected and in size it is slightly larger than the U.S. Census block group.

Indeed, the land use - travel relationship may or may not be differently estimated by how finely/ coarsely land use is measured. Boarnet and Sarmiento [56] reported that the relationship becomes stronger when land use is measured at the Census tract/ block group level than at the larger ZIP-code level. Likewise, in Manaugh and El-Geneidy's study [51], an OLS regression model found that between regional accessibility and local accessibility, the latter more strongly contributes to trip localization. By contrast, Kwan and Weber [57] assessed land use variables on differing spatial scales and concluded that their relationships on regional accessibility do not alter according to the scales, that is, "these relationships are scale invariant" (p. 110). In summary, research findings are mixed regarding whether the measurement scale of land use differentiates its effect by size. Meanwhile, Ding [58] showed through simulation that in a large spatial unit, the land use - travel relationship could be erroneously estimated. In the same vein, Sultana and Weber [59] chose the smallest zone among different aggregate units in order to reduce the errors in evaluating land use; in size, the zone was similar to the micro TAZ of this study. Greenwald and Boarnet [60] also argued that the TAZ is an appropriate scale on which the land use effect can be correctly evaluated.

As defined by the 2006 KHTS, which is employed in this study for empirical analyses, Seoul comprises 522 micro TAZs and 25 macro TAZs (each macro TAZ carries a multiple number of micro TAZs). In this sense, this study consistently 
classified destinations into the microzone inside (i.e. destination micro $\mathrm{TAZ}=$ origin micro $\mathrm{TAZ}$ ), microzone outside - macrozone inside (i.e. any micro TAZ within the origin macro TAZ, but not the origin micro TAZ), and macrozone outside, and the choice of the destination was analysed through multinomial logistic regression (reference category $=$ macrozone outside). All empirical analyses were conducted using the statistical software Stata 16.

The multinomial logistic regression models used data extracted from the Seoul subsample of the 2006 KHTS for the evaluation of all variables on trip characteristics and individual/household socio-demographics (i.e. all but those on land use) as follows; variable codes are in angle brackets " $<>$ ".

- Response variable: destination choice (or trip internalization) $<\mathrm{TIntMu}>$;

- Trip characteristics: Trip time (also called trip duration) <TTime $>$; Squared trip time $<$ TTime2 $>$ (as such, this study considered the possibility of the non-linear relationship between trip time and the likelihood of destination choice); Choice of automobile alternatives $<\mathrm{TMod} \mathrm{A}>$ (values $=$ automobile travel as reference and alternative mode travel); Trip purpose variable was not analysed because the data of the weekend travel survey, which was firstly conducted in 2006 as a supplement to the weekday main survey of the KHTS, had a substantial number of missing values in the variable, and this is not appropriate to the ML (Maximum Likelihood) estimation of logistic regression. However, trip motivation, that is, why people travel, is believed to have a considerable impact on travel behaviour. Thus, future studies are recommended to include the variable in their empirical models.

- Individual characteristics: Birth year $<$ MBirth $>$; Job type $<$ MJobR $>$ (values $=$ student as reference, homemaker/unemployed/under school age, professional/engineer, administrative/office/management, sales, service, low-skill [= agriculture/fishing/fishery + manufacturing/transportation/general labour], and others);

- Household characteristics: Household size $<\mathrm{HMemb}>$; Number of children under the school age $<\mathrm{HChil}>$; Number of private vehicles $<\mathrm{HVe}$ hi $>$; Number of sedans/vans $<\mathrm{HSV}>$; Dwelling type $<$ HHouTypR $>$ (values $=$ condominium as reference, row house, multi-family house, single-family house, and others [ $=$ officetel + others]); Dwelling ownership type $<$ HHouOwn $>$ (values = ownership as reference, Jeonse [twoyear lease], tenancy, and others); Average monthly income $<$ HIncome $>$ (values $=$ less than 1 million South Korean won as reference, 1-2, $2-3,3-5,5-10$, and equal to or more than 10)

By law, the KHTS has been done every five years since 1996. Its weekend supplementary survey collects travel data on Saturday and Sunday right after the last Thursday of October on which the weekday main survey is performed. This study extracted data from the only available KHTS, the 2006 KHTS, because unlike its successors, the 2011 and 2016 KHTSs, the 2006 KHTS assigned the same ID to an individual (the later KHTSs independently conducted the weekday and weekend surveys for which the same individual had different IDs, accordingly) and thus, this study successfully built the same sample for the weekday and weekend analytical models. As such, by controlling possible sample differences (specifically, those trip and socio-demographic characteristics that were uncontrolled in the models), this study can make a direct comparison of the coefficients of the models in examining how land use differentiates the same individual's travel between weekdays and weekends. Specifically, the Seoul subsample of the KHTS was defined by the Seoul Institute, affiliated with the Seoul Metropolitan Government. To secure a similar number of households from each of the micro TAZs, the institute applied different sampling rates: 3.6 percent to TAZs of 5,000 residents or less, 3.3 percent to $5,000-10,000$ residents, and 3.0 percent to 10,000 residents or more. Then, it chose several block groups from each TAZ (total $=5,331$ block groups out of $13,832=38.5$ percent). Finally, in each of the selected block groups, 25 households were randomly sampled and on average, 195 households were recruited in each TAZ. Figure 1 shows the distribution of the Seoul subsample, which was used for empirical analyses.

Aside from trip characteristics and individual and household socio-demographics, land use, the last factor in the model, was evaluated with public GIS/GPS data dated 1 January 2007 (in the case of population data, 31 December 2006) (Table 1). This study uploaded all data online for readers to reproduce the results of its empirical analyses: https://rive.google.com/ open?id=0B8PPoWtariY1bUIyWGhteHkzaVU. The following section reports the results of inferential analyses. Unless otherwise noted, all tests are shown at the 95 percent confidence level. 


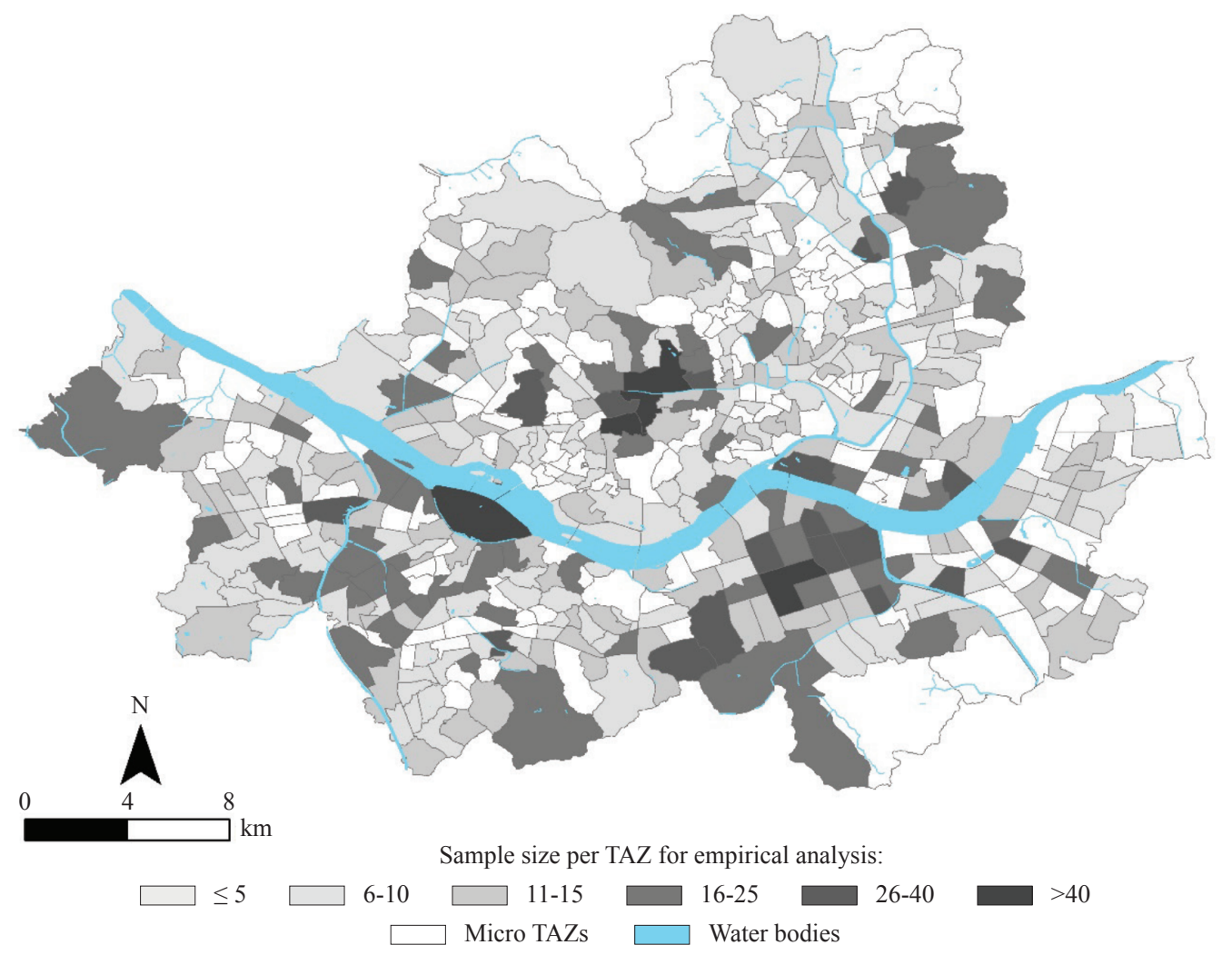

Figure 1 - Sample distribution

Table 1 - Land use variables

\begin{tabular}{|c|c|c|c|c|c|}
\hline & Variables & Definitions & Data and sources & Mean & S.D. \\
\hline 1 & Circularity (CIR) & $\begin{array}{l}\text { Isoperimetric quotient }(=4 \times \pi \times \text { area } \\
/ \text { perimeter } 2)\end{array}$ & $\begin{array}{l}\text { GIS Census units data from } \\
\text { the Korean Statistical Geo- } \\
\text { graphic Information Service }\end{array}$ & 0.932 & 0.045 \\
\hline 2 & $\begin{array}{l}\text { Daytime population } \\
\text { density (POP1_D) }\end{array}$ & $\begin{array}{l}\text { Daytime population = nighttime popu- } \\
\text { lation }+ \text { commuter inflow - commuter } \\
\text { outflow }\end{array}$ & $\begin{array}{l}\text { Numeric population data } \\
\text { from the Korean Ministry of } \\
\text { the Interior and Safety }\end{array}$ & $75,265.084$ & $59,111.736$ \\
\hline 3 & $\begin{array}{l}\text { Nighttime population } \\
\text { density (POP2_D) }\end{array}$ & $\begin{array}{l}\text { Nighttime population }=\text { resident } \\
\text { population }\end{array}$ & (Same as above) & $66,886.369$ & $34,605.655$ \\
\hline 4 & $\begin{array}{l}\text { Land use balance } \\
\text { (ENT) }\end{array}$ & $\begin{array}{l}\text { Shannon entropy }[=-\Sigma \text { number of land } \\
\text { use categories (share of a particular } \\
\text { land use } \times \text { natural log of the share) } / \\
\text { natural log of the number of land use } \\
\text { categories] (where, land use catego- } \\
\text { ries = residential, office, commercial, } \\
\text { and recreational) }\end{array}$ & $\begin{array}{l}\text { GIS land characteristics } \\
\text { data processed by the Seoul } \\
\text { Institute }\end{array}$ & 0.590 & 0.159 \\
\hline 5 & $\begin{array}{l}\text { Street intersection } \\
\text { density (CNN_D) }\end{array}$ & $\begin{array}{l}\text { Number of three- and four-way } \\
\text { intersections divided by the area of the } \\
\text { micro TAZ }\end{array}$ & $\begin{array}{l}\text { GIS street polyline data } \\
\text { from the Korean Highway } \\
\text { Management System }\end{array}$ & 966.360 & 545.314 \\
\hline 6 & $\begin{array}{l}\text { Metro facility densi- } \\
\text { ty (AVL_MET_D) }\end{array}$ & $\begin{array}{l}\text { Number of metro stations divided by } \\
\text { the area of the micro TAZ }\end{array}$ & $\begin{array}{l}\text { GIS "metro station" polygon } \\
\text { data from the Korean New } \\
\text { Address System }\end{array}$ & 1.487 & 0.938 \\
\hline 7 & $\begin{array}{l}\text { Bus facility density } \\
\text { (AVL_BUS_D) }\end{array}$ & $\begin{array}{l}\text { Number of bus stops divided by the } \\
\text { area of the micro TAZ }\end{array}$ & $\begin{array}{l}\text { GPS "bus stop" location } \\
\text { coordinates data from the } \\
\text { Seoul Bus Management } \\
\text { System }\end{array}$ & 135.884 & 61.135 \\
\hline
\end{tabular}

Note: To variables 4-7, this study applied a 0.5-mile straight-line buffer. 


\section{RESULTS}

\subsection{General results of the models}

Table 2 shows that all tests for collapsing alternatives strongly confirm the validity of the destination categorization of this study (i.e., research variables are significant at different destination ranges). Thus, instead of the typical binary grouping of the intraand inter-zonal trips, studies (at least those conducted in Seoul) [e.g. 33] are recommended to further categorize trip destinations and then, they would identify a spatial range at which a particular variable would affect the destination choice.

According to the above results of the tests for alternative combination, this study classified the destination options into microzone inside, microzone outside - macrozone inside, and macrozone outside in multinomial logistic regression models. As in $\mathrm{Ta}$ bles 3 and 4, different types of $\mathrm{R}^{2}$ values consistently indicate that the same group of research variables better accounts for the variation in the destination choice of weekday travel than of weekend travel. This is because weekday travel is more structured, and easier to explain while weekend travel is often more individualized [34].

\subsection{Trip, individual, and household characteristics}

Among trip-related and socio-demographic variables, alternative mode travel $(+)$, trip time (-), squared trip time $(+)$, and as a job type variable, the professional/engineering position (-) were found to be consistently significant regardless of the weekday - weekend difference in the trip generation day and the zone range (i.e. whether the variables were tested in relation to the macrozone inside or microzone inside) [the direction of the coefficient $(+/-)$ is in parentheses]. Regarding alternative mode travel $(+)$, as expected, if alternatives are taken instead of the automobile, a nearer destination (origin microzone/macrozone inside) was chosen. Similar to this result, through logistic regression of mode choice, Bhatta and Larsen [61] found that the intra-zonal trip - it was included as a covariate (binary dummy) - is generally shorter, and it tends to be non-motorized. Notably, the researchers highlighted that such a relationship should be interpreted as correlational, not causal. That is, they were unsure whether (1) people select destinations within the neighbourhood (internal trips) and subsequently take non-motorized modes as appropriate to the short-length trips or (2) they first decide to use non-motorized modes that cannot travel beyond a certain distance and accordingly make internal trips. In comparison, some researchers including Handy and Clifton [62] and Greenwald [40] argued that the destination and mode are simultaneously determined. Lastly, others implicitly assumed that the destination choice is accompanied by the mode choice. For example, Boarnet and Crane [63] reported that non-motorized travel is preferred within a certain maximum distance, and Sadek et al. [52] showed that walking is encouraged or motorized travel is discouraged for internal trips.

As for the job type, the professional/engineering position had a negative effect on the intra-microzone/macrozone trip. This indicates that, as expected, a trip to a more external zone is generated for commuting of the professionals and engineers whose workplaces are more spatially sparse and on weekends, their mobility or financial ability to travel allows selecting external destinations. Especially on weekdays, all types of workers except students who are assigned to the nearest school to their homes and

Table 2 - Tests for alternative combination $(n=5,091)$

\begin{tabular}{||l|c|c|c|c|c|c|c|c|c|c|c|c|c||}
\hline & \multicolumn{4}{|c|}{ Weekday travel model } & \multicolumn{4}{c|}{ Weekend travel model } \\
\cline { 2 - 16 } & \multicolumn{3}{|c|}{ Wald tests } & \multicolumn{2}{c|}{ LR tests } & \multicolumn{3}{c|}{ Wald tests } & \multicolumn{3}{c|}{ LR tests } \\
\hline \hline Alternatives tested* & $\chi^{2}$ & $\mathrm{df}$ & $p$ & $\chi^{2}$ & $\mathrm{df}$ & $p$ & $\chi^{2}$ & $\mathrm{df}$ & $p$ & $\chi^{2}$ & $\mathrm{df}$ & $p$ \\
\hline $\begin{array}{l}\text { Microzone outside - } \\
\text { macrozone inside vs. } \\
\text { microzone inside }\end{array}$ & 205.126 & 34 & 0.000 & 236.906 & 34 & 0.000 & 146.305 & 34 & 0.000 & 162.534 & 34 & 0.000 \\
\hline $\begin{array}{l}\text { Microzone outside - } \\
\text { macrozone inside vs. } \\
\text { macrozone outside }\end{array}$ & 907.244 & 34 & 0.000 & $1,603.728$ & 34 & 0.000 & $1,167.209$ & 34 & 0.000 & $1,848.852$ & 34 & 0.000 \\
\hline $\begin{array}{l}\text { Microzone inside vs. } \\
\text { macrozone outside }\end{array}$ & $1,001.968$ & 34 & 0.000 & $2,142.972$ & 34 & 0.000 & 961.477 & 34 & 0.000 & $1,536.851$ & 34 & 0.000 \\
\hline
\end{tabular}

${ }^{*} H o:$ All coefficients except constants related to a given pair of alternatives are zero (i.e. alternatives can be collapsed). 


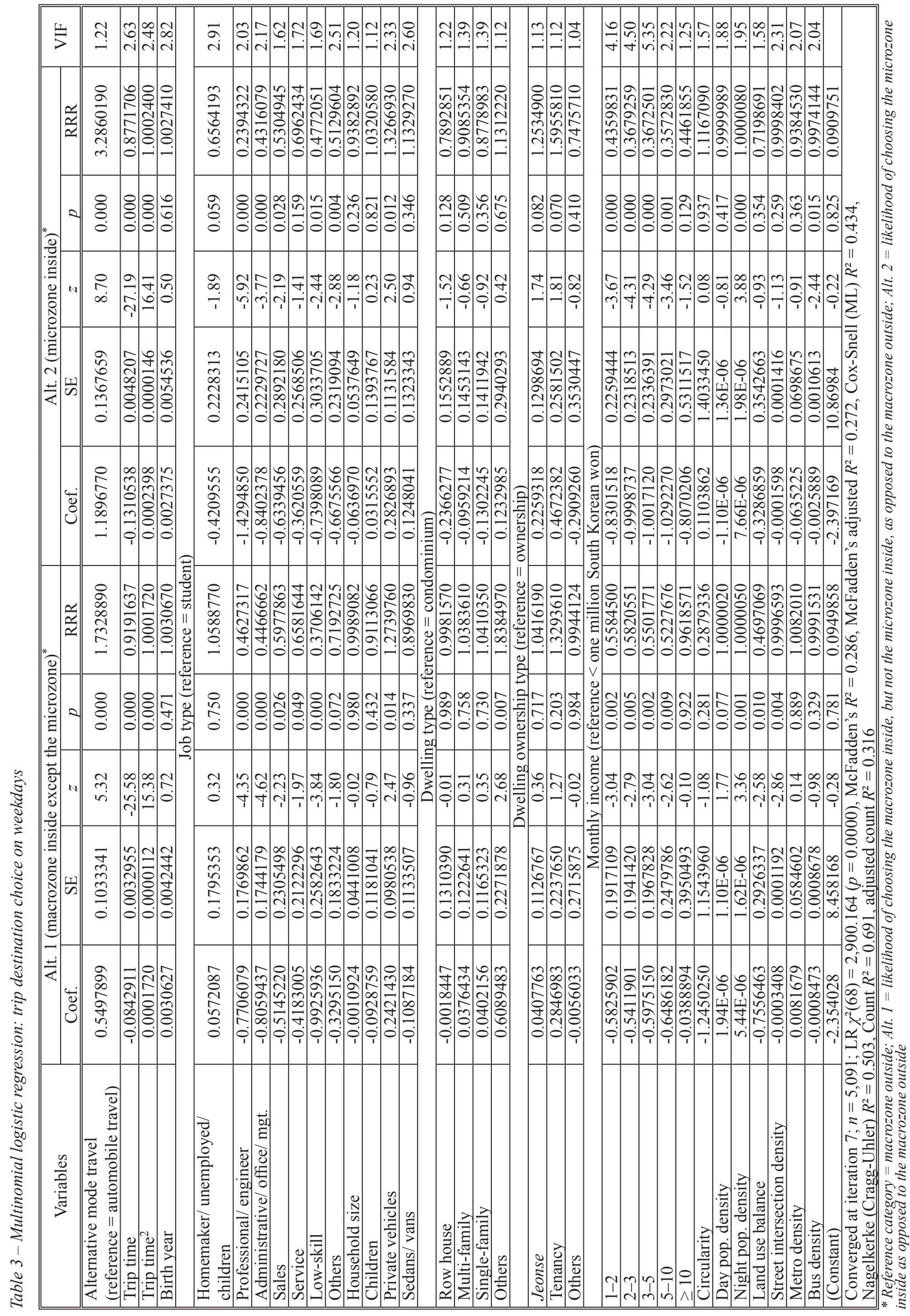




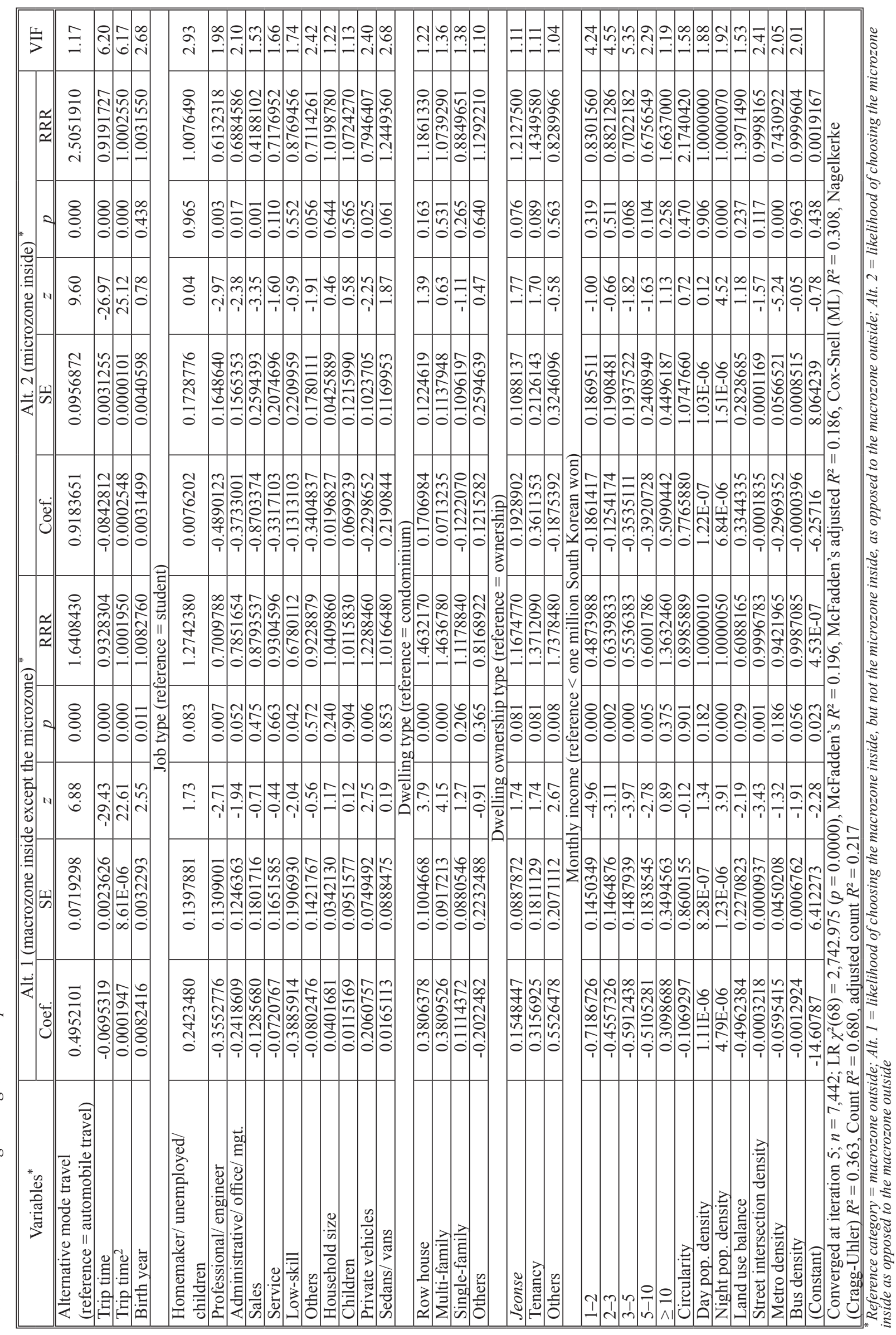


homemakers/the unemployed/children under school age who do not need to commute had a tendency to travel outside the microzone/macrozone (particularly, those in the field of "service work" tended to travel only to the macrozone outside and "others" only to the microzone outside while all other types of workers were consistently likely to choose the outsides of both zones).

While trip time (-) and its square (+) are both significant, their coefficients have the opposite directions, which suggests a U-shaped effect of the trip time. The time is a function of the speed and distance (i.e. time $=$ distance $/$ speed) and between the two, the distance is taken into account in this study by the response variable, destination choice, and consequently, the two variables together represent the effect of the speed, that is, the traffic congestion effect. Thus, the U-shape effect of trip time indicates that the congestion exerts an effect on the likelihood of choosing the internal destination only if it is above a certain level.

While this study makes the comparisons of macrozone and microzone destinations as well as of weekday and weekend travel, in these two-by-two comparisons, the following variables have consistent results in all cases, but one: (1) number of private vehicles, and (2) income categories. First, private vehicles had a role of increasing the likelihood of macrozone and microzone internal trips on weekdays and macrozone internal trips on weekends, but regarding the microzone on weekends, the role was to promote its external trips. Notably, this study evaluates the effect of automobile ownership with the "sedan/van" variable, and the "private vehicles" variable is used to estimate the ownership effect of all kinds of private vehicles, including automobile. According to the model structure, the automobile ownership becomes controlled, so the "private vehicles" variable mainly reflects the ownership of the other kinds of vehicles such as (electric) bike and motorbike; in support of this interpretation, at the 90 percent confidence level, the weekend model presents that as opposed to the "sedan/van" variable, which increases the microzone external trip, the "private vehicles" variable reduces it. Meanwhile, if this study used a separate variable to measure private vehicles other than sedans/vans, it turned to be insignificant. This would be partially attributed to the low counts of the variable: in the weekday model, mean $=0.169884, \mathrm{SD}=0.434224$, $\min .=0$, and $\max .=3$; in the weekend model, mean
$=0.161260, \mathrm{SD}=0.419592$, min. $=0$, and $\max .=$ 3 . From this perspective, this result implies that as mainly used for short-length trips, these non-automobile modes contribute to facilitating microzone and macrozone inside trips on weekdays and on weekends when people usually make trips to leisure and other non-daily destinations, the modes encourage the generation of a trip to a macrozone destination (i.e., microzone outside, but macrozone inside). Lastly, it should be noted that the variable of "private vehicles" (and "sedan/van", also) presents the ownership effect and how the selection/use of a certain mode exerts an effect has been reported above, using the "alternative mode travel" variable: The alternative mode choice increases the microzone and macrozone inside trip without regard to whether the trip is made on weekdays or weekends.

In respect to income, compared to the reference category, which is the lowest income class (less than 1 million South Korean won), almost all upper classes turned out to positively affect the microzone and macrozone outside trips. As an exception, different from its lower four classes $(1-2,2-3,3-5$, and 5-10 million won), the highest income class (equal to or more than 10) was not significant in any case. This result may indicate that such a super-high income class has a unique travel pattern.

Aside from the highest income category, the higher the income, the more likely the microzone and macrozone external destination was to be chosen for weekday travel and the macrozone external destination for weekend travel. However, as a variable that represents mobility and travel ability, none of the income classes made a difference in selecting the microzone inside or outside on weekends.

Among five dwelling type variables, two were significant in differentiating the macrozone-related trip in a particular model, but not both. The likelihood of choosing the macrozone inside destination was positively affected by the variable of "officetel and others" for weekday travel and by the "multi-family house" variable for weekend travel. First, regarding officetel (a compound of office and hotel), the result well reflects the land use settings of Seoul as a building type that combines work and residential purposes together, officetel is typically established in business districts and people tend to choose this dwelling type considering job accessibility along with its affordability (i.e. low price). Secondly, in the case of multi-family housing, in Seoul, it is generally favoured by lower-class 
people and thus, the result may imply that they lack the ability to travel outside the macrozone for weekend leisure and other non-mandatory purposes.

\subsection{Land use characteristics}

With regard to land use characteristics, firstly, in the weekday model, areas with high nighttime population density $(+)$ turned out to have a high tendency to generate microzone and macrozone inside trips. Land use balance (-) and intersection density (-) negatively worked only on the macrozone inside trip (i.e. a trip that goes beyond the microzone and toward the macrozone) and bus facility density (-) only on the microzone inside trip. Note that in multinomial logistic regression settings, a negative effect on one response alternative indicates a positive effect on all other alternatives and thus, the results on land use balance (-) and intersection density (-) they reduce the macrozone inside trip - suggest that these variables may increase the microzone inside trip as well as the macrozone outside trip.

Secondly, in the weekend model, as with the weekday model, nighttime population density $(+)$ was found to be significant both in the microzone and macrozone inside trips. As such, it became the only land use variable that is consistently significant both in the microzone and macrozone as well as both on weekdays and weekends. By contrast, daytime population density was not significant in any zone and without regard to the weekday - weekend difference. (Also, circularity was insignificant in all cases.) Regarding other variables, land use balance $(-)$ and street intersection density (-) were significant in the reduction only of the macrozone inside trip and metro facility density (-) only of the microzone inside trip.

Meanwhile, in relation only to the macrozone inside trip, the same variables were found to be significant in the weekday and weekend models: nighttime population density $(+)$, land use balance $(-)$, and street intersection density (-). However, if the weekday and weekend trips are compared in relation only to the microzone inside trip, one can find that different variables become significant: bus facility density (-) for weekday travel and metro facility density (-) for weekend travel. Table 5 lists significant land use variables in the two multinomial logistic regression models, each of which was specified for weekday and weekend travel

\section{DISCUSSION}

A feature of this study is that internal trips were classified into trips to the microzone inside and those to the macrozone inside (but, beyond the microzone). One variable was found to be consistently significant in the weekday and weekend models regardless of the zone size: nighttime population density facilitated micro and macrozone-inside trips. Regarding its magnitudes, both on weekdays and on weekends, it had a less strong effect on the trip to the microzone outside (i.e. macrozone inside) than to its inside (5.44E-06 versus 7.66E-06 in the weekday model and 4.79E-06 versus 6.84E-06 in the weekend model). Likewise, Sadek et al. [52] found through literature review that land use has a less strong effect on external travel than on internal travel.

Except nighttime population density, which was significant in all of the four cases (i.e. weekday microzone, weekday macrozone, weekend microzone, and weekend macrozone), both on weekdays and weekends, the land use balance and street intersection density were significant concerning the macrozone, only; they both had negative effects. In relation to the microzone inside trip, public transit characteristics had significant (negative) effects: the densities of bus facilities on weekdays and of metro stations on weekends.

First, in regard to land use balance or entropy, this concept is intended to increase destinations within a microzone or a walkable distance. Thus, its negative effect on the macrozone inside trip may imply that land use balance pulls macrozone-inside facilities compactly into a smaller local area, so it

Table 5 - Land use effects: weekday - weekend split $\times$ macrozone - microzone split

\begin{tabular}{||l|l|l||}
\hline \hline & \multicolumn{1}{|c||}{ Weekday travel } & \multicolumn{1}{|c||}{ Weekend travel } \\
\hline \hline $\begin{array}{l}\text { Macrozone inside } \\
\text { and microzone outside) }\end{array}$ & $\begin{array}{l}\text { Nighttime population density }(+) \\
\text { Land use balance (-) } \\
\text { Street intersection density (-) }\end{array}$ & $\begin{array}{l}\text { Nighttime population density }(+) \\
\text { Land use balance (-) } \\
\text { Street intersection density (-) }\end{array}$ \\
\hline Microzone inside & $\begin{array}{l}\text { Nighttime population density }(+) \\
\text { Bus facility density }(-)\end{array}$ & $\begin{array}{l}\text { Nighttime population density }(+) \\
\text { Metro facility density (-) }\end{array}$ \\
\hline
\end{tabular}

Note: The direction of the coefficient (+/-) is in parentheses; circularity and daytime population density were not significant in any models. 
reduces trips that go beyond the microzone and toward the macrozone, but because the concept is not concerned with drawing macrozone-outside facilities - they have wider service ranges (so, they are relatively scarce) - into the micro/macrozone, trips going outside the macrozone are not affected. In fact, this interpretation is in line with the findings of several previous studies. Sadek et al. [52] categorized destination TAZs by distance and reported that land use entropy is positively associated with the selections of the origin TAZ inside and its neighbouring TAZs, but its relationships with outer TAZs are insignificant. Also, Soltani and Ivaki [50] found that the relationship between land use diversity and the between-zone trip is insignificant and subsequently suspected that the insignificance is because the diversity affects the generation of the within-zone trip, which was not counted in their study. Particularly regarding the selection of the macrozone outside destination, Handy and Clifton [62] similarly showed through linear regression of survey data that the housing - shopping mix does not decrease the distance of automobile travel and rather results in the tendency that residents drive to more distant stores.

As reported as a major land use variable $[29,30$, $64,65]$, street intersection density in the microzone was found to bring about a similar result with that of land use balance. That is, because it increases accessibility to short-distance microzone-inside destinations, those trips going beyond the microzone (toward the macrozone) may be attracted to the inside, but because it does not evaluate street networks in the macrozone, long-distance macrozone-outside trips are not differentiated; Greenwald [40] also found a positive relationship between the intersection density and the possibility of external travel. This finding may provide evidence for the conceptual argument that the effects of compact developments are limited to localized areas [66]. Notably, however, another possible explanation could be that while according to the street width, link length, and others, street connectivity benefits not only walking used for short-length trips, but also automobile travel, which is used for long-length macrozone outside trips [67] - as stated earlier, the choice of the automobile was found to encourage the macrozone outside trip - street networks in Seoul work both for walking and automobile travel.
At the macrozone level, significant variables were not different between the weekday and weekend models: land use balance and street intersection density (in addition to nighttime population density, which was significant in all cases, that is, also on the microzone scale). At the microzone level, transit systems generally played a role of facilitating travel beyond a walkable distance, but in particular, bus and metro systems exerted an effect on different days: the chance of microzone-inside trips was reduced by bus availability on weekdays, but by metro availability on weekends. By identifying the different roles of the bus and metro systems, this finding expands the Soltani and Ivaki's argument [50] that overall, public transit has a significant effect on the choice of the internal/external destination. The finding can be understood in relation to the fact that weekday trips have mostly mandatory purposes for which destinations are typically fixed, whereas a high proportion of weekend trips have discretionary purposes and flexible (changeable) destinations [20, 21]. That is, the finding may be because bus riders need to be equipped with a due amount of prior information on complex bus lines and stop locations (in Seoul, bus stops $=25,943$ and metro stations $=$ 259), so buses are used to travel to familiar weekday destinations outside their neighbourhood as opposed to metro services that are more structured/ systematized, and taken to travel to less familiar weekend destinations. In fact, according to the Korean Ministry of Land, Infrastructure and Transport [68], despite its stable population size, the weekend metro ridership in Seoul is in a steadily increasing trend.

Alternately, the finding that microzone-inside trips vary by bus availability on weekdays and by metro availability on weekends can be interpreted based on the spatial balances/distributions of the two types of transit systems: Metro facilities are built only if a certain amount of demand is secured [69], so they become more densely located in urban centres while bus stops are more evenly dispersed throughout Seoul owing to its bus line trunk-andfeeder approach [for details, see Allen [70]]. Then, from the perspective of the compensatory travel hypothesis - residents living in compact areas have a repressed desire to travel $[71,72]$ on weekdays, and they make it up by travelling outside for a longer distance on weekends [73] - the finding may indicate that public transit systems generally promote external trips, but especially those living in urban 
centres with a high density of metro stations are more strongly motivated to embark on external trips on weekends.

\section{CONCLUSION}

The aim of this study is to expand the understanding of the land use - travel relationship by focusing on weekend travel in comparison to weekday travel and by evaluating the destination choice as a less investigated measure of travel. Among differences from the previous studies, first, in terms of the destination choice, this study considered the TAZ inside and outside trips together and by categorizing destinations into three ranges (i.e. microzone inside, microzone outside - macrozone inside, and macrozone outside), it reflected the competitive relationships among the destination options through multinomial logistic regression. A second difference is that unlike previous multi-day studies, this study separately specified the weekday and weekend travel models and by applying the same sample to the two models, it controls variations by the characteristics of the sample itself. For the evaluation of the models, data on land use variables (circularity, daytime and nighttime population densities, land use balance, street intersection density, and metro and bus facility densities) were obtained from the public GIS systems and those on the other variables (i.e. trip characteristics and the individual's/household's socio-demographics) were extracted from the Seoul subsample of the 2006 KHTS.

One major finding of this study is that among trip characteristics, the "use" of an automobile alternative for travel was consistently associated with the tendency to choose further inner zones. Moreover, the "ownership" of such an alternative - (electric) bike and motorbike, for example, was found to increase internal trips on weekdays (toward the macrozone and microzone insides) and on weekends (to the macrozone inside). Meanwhile, this study evaluated the effect of traffic congestion using trip time and its square variable. As such, the congestion was found to significantly increase the tendency to choose the internal destination only after it is aggravated beyond a certain degree.

Among socio-demographic variables, regarding job types, all categories standing for paid employment resulted in the higher possibility of the microzone/macrozone outside trip on weekdays, compared to the student and unemployed categories. With regard to the income, relative to the base, the lowest category, higher income categories tended to increase the likeliness of the microzone/macrozone outside trip on weekdays and weekends. Lastly, the effects of housing types were somewhat particular to the Korean settings: Officetel, which is usually selected considering job accessibility, encouraged weekday (macrozone) internal trips and row house and multi-family houses, which are favoured by low-income people, restricted weekend (macrozone) external trips.

In terms of land use characteristics, first, regardless of weekday, weekend, microzone, and macrozone differences, nighttime population density was found to be always significant in increasing internal trips. Daytime density, however, was not significant in any cases, as with circularity. Among the other land use variables, land use balance and street intersection density contributed to making a trip within the microzone and beyond the macrozone consistently on weekdays and weekends. While in theory [66], the range of the effect of compact land use is spatially limited, the finding implies that the spatially localized effect would be particular to these two variables. Meanwhile, on the macrozone scale, significant variables were consistent on weekdays and weekends (i.e. nighttime population density, land use balance, and street intersection density), but on the scale of the microzone, they were differentiated: External trips beyond the walkable distance were facilitated by bus services on weekdays and metro services on weekends. Such a difference may be because for weekday external travel whose destinations and departure/arrival schedules are mostly fixed, complex but highly accessible bus services are favoured in Seoul, whereas for weekend travel for which the destinations and schedules are more flexible/irregular, highly structured metro services are taken in order to compensate for the low familiarity with the destinations and schedules.

In summary, compared to the effects of land use on weekday and weekend travel, those of destination choice-related variables might be consistent on a larger macro scale of land use, which is a subject in regional planning, but not on a micro scale; its land use is a major concern for urban designers and public health researchers/practitioners. Therefore, when the influences of land use variables are analysed, studies are recommended to estimate them on multiple scales and in the same sense, it is desirable to continue studying on the spatial ranges of the effects of various local land use variables. 


\section{ACKNOWLEDGEMENT}

This research was supported by the Basic Science Research Program through the National Research Foundation of Korea (NRF) funded by the Ministry of Science and ICT (NRF-2017R1C1B1007433).

김태형, 도시 및 지역계힉학 박사 ${ }^{1}$

E-mail: taehyoung.gim@snu.ac.kr

1 서울대학교 환경대학원, 협동과정 조경학, 환경 계획연구소

08826 서울특별시 관악구 관악로 1 82동 222호

\section{토지이용이 통행의 내부목적지 선택에 미치는 영향: 주중통행과 주말통행의 비교}

\section{초록}

토지이용-통행 관계에 관한 연구 중 주말통행 및 목적지선택을 대상으로 하는 경우는 드물다. 본 연구는 토지이용-목적지선택 관계가 주중과 주말에 어떻게 다른지 평가하기 위해 두 개의 다항 로지스틱 회귀모형을 개발하고 여기에서 목적지를 소존 내부, 소존 외부-대존 내부, 대존 외부의 셋으로 구분한다. 분석결과, 자동차 대안수단의 선택 및 소유가 소존 내부 선택과 관련이 있고 직업과 소득은 외부통행에 기여하는 것으로 나타난다. 토지이용 변수 중에서는 야간인구밀도가 존 규모나 주중-주말 차이와 관계없이 일관되게 내부통행을 증가시키며 반대로 주간인구밀도는 모든 경우에 비유의한 것으로 도출된다. 토지이용엔트로피와 도로연결성은 소존을 넘어 대존으로 진출하는 통행을 억제하고 대중교통시스템 변수들은 소존을 넘어서는 통행을 촉진하는 것으로 보인다. 두 개 대중교통시스템 변수 중에 소존 선택은 특히 주중의 경우는 낮은 버스정류장밀도, 주말에는 낮은 지하철역밀도와 관련이 있다.

\section{핵심어}

토지이용; 목적지선택; 주중-주말 비교; 다항 로지스틱 회귀분석; 서울

\section{REFERENCES}

[1] Mitchell RB, Rapkin C. Urban Traffic: A Function of Land Use. New York: Columbia University Press; 1954.

[2] Levinson H, Wynn FH. Effects of density on urban transportation requirements. Highway Research Record. 1963;2: 38-64.

[3] Ewing R, Bartholomew K, Winkelman S, Walters J, Chen D. Growing Cooler: The Evidence on Urban Development and Climate Change. Washington, D.C.: Urban Land Institute; 2008.

[4] Environmental Protection Agency. Our built and natural environments: A technical review of the interactions among land use, transportation, and environmental quality. Washington, DC: Environmental Protection Agency; 2013.

[5] Handy S, Mokhtarian P. Growing Cooler: The Evidence on Urban Development and Climate Change. Journal of the American Planning Association. 2008;75(1): 95-6.

[6] Badoe DA, Miller EJ. Transportation-land-use interaction: empirical findings in North America, and their implications for modeling. Transportation Research $D$. 2000;5(4): 235-63.

[7] Næss P. Residential location affects travel behavior — but how and why? The case of Copenhagen metropolitan area. Progress in Planning. 2005;63(2): 167-257.

[8] Handy SL. Smart growth and the transportation-land use connection: What does the research tell us? International Regional Science Review. 2005;28(2): 146-67.

[9] Handy SL, Boarnet MG, Ewing R, Killingsworth RE. How the built environment affects physical activity: Views from urban planning. American Journal of Preventive Medicine. 2002;23(2, Supplement 1): 64-73.

[10] Stopher PR, Ahmed A, Liu W. Travel time budgets: new evidence from multi-year, multi-day data. Transportation. 2017;44(5): 1069-82.

[11] Raux C, Ma T-Y, Cornelis E. Variability in daily activity-travel patterns: the case of a one-week travel diary. European Transport Research Review. 2016;8(4): 26.

[12] Kim S, Song M, Chung JH. A study on weekdays and weekends travel patterns and trip maker's characteristics in the Seoul Metropolitan Area. Proceedings of the $65^{\text {th }}$ Korean Society of Transportation Conference, Goyang, Korea. Korean Society of Transportation; 2011. p. 77-82.

[13] Oh S, Ryu J-Y. Need for transportation infrastructure investment in consideration of the demand for weekend leisure travel. Anyang, Korea: Korea Research Institute for Human Settlements; 2007.

[14] Forsyth A, Oakes JM, Schmitz KH, Hearst M. Does Residential Density Increase Walking and Other Physical Activity? Urban Studies. 2007;44(4): 679-97.

[15] Saelens BE, Sallis JF, Frank LD. Environmental correlates of walking and cycling: Findings from the transportation, urban design, and planning literatures. Annals of Behavioral Medicine. 2003;25(2): 80-91.

[16] Rajamani J, Bhat CR, Handy S, Knaap G, Song Y. Assessing the impact of urban form measures on nonwork trip mode choice after controlling for demographic and level-of-service effects. Transportation Research Record. 2003;1831: 158-65.

[17] Korea Transport Institute. 2010 Weekend Travel Survey. Gwacheon, Korea: Ministry of Land, Infrastructure and Transport; 2011.

[18] Suh D-H, Jang Y-J, Lee S-I. Analyzing urban structural relationship between work trip and weekend leisure trip in consideration of compensatory mechanism: A case study for the Seoul Metropolitan Area. Journal of Korea Planning Association. 2011;46(7): 89-101.

[19] Jang Y-J, Lee S-I. An impact analysis of the relationship between the leisure environment at people's places of residence in Seoul and their leisure travel on weekends. Journal of the Korea Planning Association. 2010;45(6): 85-100. 
[20] Goulias KG, Kitamura R. Recursive Model System for Trip Generation and Trip Chaining. Transportation Research Record. 1989;1236: 59-66.

[21] Goulias KG, Pendyala RM, Kitamura R. Practical method for the estimation of trip generation and trip chaining. Transportation Research Record. 1990;1285: 47-56.

[22] Lee Y, Washington S, Frank LD. Examination of relationships between urban form, household activities, and time allocation in the Atlanta Metropolitan Region. Transportation Research Part A: Policy and Practice. 2009;43(4): 360-73.

[23] Liu RR, Deng Y. Developing statewide weekend travel-demand forecast and mode-choice models for New Jersey. In: Sloboda BW, editor. Transportation Statistics. Fort Lauderdale, FL: J. Ross Publishing; 2009. p. 231-48.

[24] Ewing R, Cervero R. Travel and the built environment: A meta-analysis. Journal of the American Planning Association. 2010;76(3): 265-94.

[25] Beatley T. Green Urbanism: Learning from European cities. Washington, DC: Island Press; 2000.

[26] Van Diepen AML, Voogd H. Sustainability and planning: Does urban form matter? International Journal of Sustainable Development. 2001;4: 59-74.

[27] Ewing R. Beyond density, mode choice, and single-purpose trips. Transportation Quarterly. 1995;49(4): 15-24.

[28] Pipkin JS. Disaggregate models of travel behaviour. In: Hanson S, editor. Geography of Urban Transportation. New York: The Guilford Press; 1995. p. 188-218.

[29] Zhang M. The Role of Land Use in Travel Mode Choice: Evidence from Boston and Hong Kong. Journal of the American Planning Association. 2004;70(3): 344-60.

[30] Gim T-HT. Land use, travel utility, and travel behavior: An analysis from the perspective of the positive utility of travel. Papers in Regional Science. 2018;97(Supp 1): 169-193. Available from: doi:10.1111/pirs. 12239

[31] Demissie MG, Phithakkitnukoon S, Kattan L. Trip distribution modeling using mobile phone data: Emphasis on intra-zonal trips. IEEE Transactions on Intelligent Transportation Systems. 2019;20(7): 2605-17.

[32] Manout O, Bonnel P. The impact of ignoring intrazonal trips in assignment models: A stochastic approach. Transportation. 2019;46(6): 2397-417.

[33] Gim T-HT. An analysis of the relationship between land use and weekend travel: Focusing on the internal capture of trips. Sustainability. 2018;10(2): 425.

[34] Gim T-HT. Full random coefficients multilevel modeling of the relationship between land use and trip time on weekdays and weekends. Sustainability. 2017;9(10): 1824.

[35] Troped PJ, Wilson JS, Matthews CE, Cromley EK, Melly SJ. The Built Environment and Location-Based Physical Activity. American Journal of Preventive Medicine. 2010;38(4): 429-38.

[36] Ogilvie D, Mitchell R, Mutrie N, Petticrew M, Platt S. Personal and environmental correlates of active travel and physical activity in a deprived urban population. International Journal of Behavioral Nutrition and Physical Activity. 2008;5(1): 43.

[37] Lin J-J, Yu T-P. Built environment effects on leisure travel for children: Trip generation and travel mode. Transport Policy. 2011;18(1): 246-58.
[38] Witten K, Blakely T, Bagheri N, Badland H, Ivory V, Pearce J, et al. Neighborhood Built Environment and Transport and Leisure Physical Activity: Findings Using Objective Exposure and Outcome Measures in New Zealand. Environmental Health Perspectives. 2012;120(7): 971-7.

[39] Cervero R, Duncan M. Walking, bicycling, and urban landscapes: Evidence from the San Francisco Bay Area. American Journal of Public Health. 2003;93(9): 147883.

[40] Greenwald MJ. The relationship between land use and intrazonal trip making behaviors: Evidence and implications. Transportation Research Part D: Transport and Environment. 2006;11(6): 432-46.

[41] Cervero R. Jobs-Housing Balancing and Regional Mobility. Journal of the American Planning Association. 1989;55(2): 136-50.

[42] Cervero R, Duncan M. 'Which Reduces Vehicle Travel More: Jobs-Housing Balance or Retail-Housing Mixing? Journal of the American Planning Association. 2006;72(4): 475-90.

[43] Levine J. Rethinking Accessibility and Jobs-Housing Balance. Journal of the American Planning Association. 1998;64(2): 133-49.

[44] Wang D, Chai Y. The jobs-housing relationship and commuting in Beijing, China: the legacy of Danwei. Journal of Transport Geography. 2009;17(1): 30-8.

[45] Giuliano G, Small KA. Is the Journey to Work Explained by Urban Structure? Urban Studies. 1993;30(9): 1485500 .

[46] Choi S, Choo S, Kim S. Exploring the influences of compact development on zone-based travel patterns: A case study of the Seoul metropolitan area. Transportation Letters. 2020;12(5): 316-328.

[47] Park K, Sabouri S, Lyons T, Tian G, Ewing R. Intrazonal or interzonal? Improving intrazonal travel forecast in a four-step travel demand model. Transportation. May 2019. Available from: doi:10.1007/s11116-019-10002-0

[48] Handy SL. Does the built environment influence physical activity? Examining the evidence: Critical assessment of the literature on the relationships among transportation, land use, and physical activity. TRB Special Report 282, 2005.

[49] Zhang M, Kone A, Tooley S, Ramphul R. Trip internalization and mixed-use development: A case study of Austin, Texas. Austin, TX: Center for Transportation Research; 2009.

[50] Soltani A, Ivaki YE. The influence of urban physical form on trip generation, evidence from metropolitan Shiraz, Iran. Indian Journal of Science and Technology. 2011;4(9): 1168-74.

[51] Manaugh K, El-Geneidy A. What makes travel 'local': Defining and understanding local travel behaviour. Journal of Transport and Land Use. 2012;5(3).

[52] Sadek AW, Wang Q, Su P, Tracy A. Reducing vehicle miles traveled through smart land-use design. Albany, NY: New York State Energy Research and Development Authority and Department of Transportation; 2011.

[53] Zhang L, Hong JH, Nasri A, Shen Q. How built environment affects travel behavior: A comparative analysis of the connections between land use and vehicle miles 
traveled in US cities. Journal of Transport and Land Use. 2012;5(3): 40-52.

[54] Hong J, Shen Q, Zhang L. How do built-environment factors affect travel behavior? A spatial analysis at different geographic scales. Transportation. 2014;41(3): 419-40.

[55] Gim T-HT. Testing the reciprocal relationship between attitudes and land use in relation to trip frequencies: a nonrecursive model. International Regional Science Review. 2016;39(2): 203-27.

[56] [56] Boarnet MG, Sarmiento S. Can land-use policy really affect travel behaviour? A study of the link between non-work travel and land-use characteristics. Urban Studies. 1998;35(7): 1155-69.

[57] Kwan M-P, Weber J. Scale and accessibility: Implications for the analysis of land use-travel interaction. Applied Geography. 2008;28(2): 110-23.

[58] Ding C. The GIS-based human-interactive TAZ design algorithm: examining the impacts of data aggregation on transportation-planning analysis. Environment and Planning B: Planning and Design. 1998;25(4): 601-16.

[59] Sultana S, Weber J. Journey-to-work patterns in the age of sprawl: Evidence from two midsize Southern metropolitan areas. Professional Geographer. 2007;59(2): 193-208.

[60] Greenwald M, Boarnet M. Built Environment as Determinant of Walking Behavior: Analyzing Non-work Pedestrian Travel in Portland, Oregon. Transportation Research Record. 2001;1780: 33-42.

[61] Bhatta BP, Larsen OI. Are intrazonal trips ignorable? Transport Policy. 2011;18(1): 13-22.

[62] Handy SL, Clifton KJ. Local shopping as a strategy for reducing automobile travel. Transportation. 2001;28(4): 317-46.

[63] Boarnet M, Crane R. The influence of land use on travel behavior: specification and estimation strategies.
Transportation Research A. 2001;35(9): 823-45.

[64] Gim T-HT. Influences on trip frequency according to travel purposes: a structural equation modeling approach in Seoul, South Korea. Environment and Planning B: Planning and Design. 2011;38(3): 429-46.

[65] Gim T-HT. A comparison of the effects of objective and perceived land use on travel behavior. Growth and Change. 2011;42(4): 571-600.

[66] Maat K, van Wee B, Stead D. Land use and travel behaviour: expected effects from the perspective of utility theory and activity-based theories. Environment and Planning B: Planning and Design. 2005;32: 33-46.

[67] Ewing R, Cervero R. Travel and the built environment: a synthesis. Transportation Research Record. 2001;1780: 87-113.

[68] Korean Ministry of Land Infrastructure and Transport. Ridership of urban rail transit by year 2017. Available from: http://www.index.go.kr/potal/main/EachDtlPageDetail.do?idx_cd $=1259$

[69] Stone B, Mednick AC, Holloway T, Spak SN. Is compact growth good for air quality? Journal of the American Planning Association. 2007;73(4): 404-18.

[70] Allen H. Bus reform in Seoul, Republic of Korea: Case study prepared for Global Report on Human Settlements 2013. Nairobi, Kenya: United Nations Human Settlements Programme; 2013.

[71] Hupkes G. The law of constant travel time and trip-rates. Futures. 1982;14(1): 38-46.

[72] Marchetti C. Anthropological invariants in travel behavior. Technological Forecasting and Social Change. 1994;47(1): 75-88.

[73] Holden E, Norland IT. Three challenges for the compact city as a sustainable urban form: Household consumption of energy and transport in eight residential areas in the Greater Oslo Region. Urban Studies. 2005;42(12): 214566. 